\title{
ARTIFICIALLY NOURISHED AND CONSTRUCTED BEACHES
}

\author{
Jay V. Hall, Jr. \\ Chief, Engineering Division, Beach Erosion Board \\ Department of the Army, Washington, D. C.
}

\section{IN TRODUC TION}

Construction, improvement and maintenance of beaches through the artificial deposition of sand on the shore is rapidly gaining prominance in the field of shore protection engineering. The trend toward this type of shore improvement has resulted from our changing economy, modes of transportation and recreational habits. As our mode of transportation improved and people had more time for recreation, beach resorts developed and grew to proportions typified by Atlantic City, N. J. Numerous factors control the growth of a resort of this size but undoubtedly all will agree that it is the beach which is the resorts' primary asset. This fact was recognized very early in resort development and every effort was made to preserve the beaches from the ravages of the sea. Unfortunately the science of shore protection lagged behind resort development and beaches soon became covered with a maze of structures which discouraged rather than encouraged their use. At this point something had to be done to restore the beaches to their original attractiveness. The obvious means for this improvement was to eliminate all structures as far as possible and to replace the beach material which had been removed. Was it possible that such plans could succeed? Careful study convinced a number of engineers that beach restoration employing artificial nourishment had possibilities and in some instances might be the most economical as well as best method of improvement. More importantly, there has developed a growing recognition of the fact that preventing erosion by means of protective structures is a dangerous practice, in the sense that in many cases such protection is secured at the expense of producing an ever expanding problem area. Artificial nourishment, on the other hand, benefits not only the shore upon which it is placed but adjoining shores as well. The economic merit of this type of treatment has often been difficult to evaluate because of uncertainties in prospective maintenance cost and in determination of the extent of shore which would be benefited. It is needless to say here that although the method has been employed without a complete understanding of all the factors controlling an ideal installation the results have been gratifying.

It is the purpose of this paper; first, to outline the criteria pertinent to the design of artificially nourished beaches and explain how each is derived and used; second, to present a brief history of five areas where the four types of artificial nourishment have been tried; namely the offshore dumping method, the stockpiling method, the continuous supply method, and the direct placoment method; and third, to present a tabular record of a great number of artificially nourished and constructed beaches including factors relating to their placement and economic life. 


\section{DESIGN CRITERIA}

At the present time although the design of artificially nourished and constructed beaches has not been firmly estaklished on a scientific basis, advances have been made in the field of wave motion and the effect waves have on the shore which have established it on better than a rule of thumb basis. In the following paragraphs criteria for the design of artificially nourished and constructed beaches will be enumerated and their derivation and use will be explained.

The first task in approaching a design problem of this nature is to determine quantitatively the deficiency in material supply in the problem area. This is the rate of loss of beach material and is the rate at which the material supply must be increased to balance the transport capacity of littoral forces so that no net loss will occur. If there is no natural supply available, as may be the case on shores down drift from a major littoral barrier, the deficiency in supply will be equal to the full rate of littoral drift. If the problem area is part of a continuous and unobstructed sandy beach, it is likely that the deficiency will be relatively small compared with the drift rate. Comparison of surveys over a long period of time is the only accurate means of determining the rate of nourishment required to maintain stability of the shore. Since surveys in suitable detail for volumetric measurement are rarely available at problem areas, approximations computed from changes in the shore position determined by air photos or any other suitable records is often necessary. For such approximations a rule of thumb equation wherein one square foot of surface area equals one cubic yard of beach material appears to provide acceptable values on exposed seacoasts. For less exposed shores this ratio would probably result in volumetric estimates somewhat in excess of the true figure and would thus produce conservative values.

The next and equally important task is the determination of the predominant direction of littoral drift. This is most generally determined by studying the shore configuration at groins, jetties or other littoral barriers. The major accumulation of littoral material occurs on the updrift side of such barriers, however in the case of minor barriers such as short groins, seasonal variability or storm effects may obliterate the predominant trend. Care must be taken to avoid misinterpretation in such cases. Seasonal trends should be determined and evaluated where doubt exists on the basis of available evidence.

Unfortunately, or maybe fortunately, the engineer has not covered each sector of our entire shore line with structures whereby this determination of the rate of drift can be made. In the event that structures are not available on a sandy beach, or an area is to be improved that is devoid of littoral materials, another method of determining these factors must be employed. A rather long laborious method is available for use, which indicates the direction of the predominant littoral forces quite accurately, but indicates only the relative strength of the littoral forces along selected stretches of the shore. 


\section{ARTIFICIALLY NOURISHED AND CONSTRUCTED BEACHES}

This method of proceedure involves the use of the techniques of hindcasting wave data from synoptic weather charts to determine the wave climate over a period of years in a given area; the use of refraction diagrams to bring this wave budget into shallow water; and the use of vector diagrams to determine the resultant di rection and magnitude of the wave energy whlch establishes the predominent direction and relative strength of the littoral movement. The predominant direction of the littoral drift is considered to coincide with the direction of the resultant of the flow of wave energy, and the relation between the strength of the littoral movement is determined to be the longshore component of the wave energy acting along its ostablished direction toward the beach. In view of the lack of knowledge of the characteristics of the boundary conditions imposed by the surf zone it is not possible at the present time to actually relate the longshore component of the wave energy to a quantitative determination of littoral drift. In other words only the relative strengths of the littoral forces in the various related locations al ong a stretch of beach under study should be used.

Having established the direction and magnitude of the forces that will operate on a proposed fill the next problem to be encountered is that of selecting a suitable beach material. Unfortunately adequate criteria have not been established for evaluating the qualities of beach materials. However, a limited amount of information pertaining to the sorting of beach ands and the relation of grain size to beach slope are of value in selecting materials for artificial nourishment. When sand is deposited on a shore the waves operating in the area immediately start a sorting action on the surface layer of the fill moving the finer particles seaward leaving the coarser material shoreward of the plunge point. This sorting action continues until a layer of coarse particles compatible with the wave spectrum of the area armors the beach and renders it relatively stable. However, if the armor is broken due to a storm, the underlying material is again subjected to the sorting process. In view of this sorting process beach materials containing clay lenses or discolored particles may bo used with the assurance that natural processes will clean the sand and make it an entirely suitable material for nourishment. Experience with the fills at Anaheim Bay, California, and $\mathrm{Palm}_{\mathrm{m}}$ Bach, Plorida, both of which contained foreign matter confirm this statement.

During the period of sorting, the beach slope is also adjusted until it becomes compatible with the grain size distribution of the sorted material. In view of this fact, a desired beach slope may be obtained by randomly placing material of a gradation that will assume the desired slope after sorting and slope adjustment. The selection of a material of the proper gradation to produce the desired slope as far as is known at the present time can only be determined by analyzing the sand taken from a beach in the surrounding area which has a similar orientation and is acted upon by the same wave forces. Sand selected for artificial nourishment should ideally contain the same gradation of materials as those found on the beach to be nourished if the original beach slope is to be maintained. 


\section{COASTAL ENGINEERING}

Material of coarser characteristics may be expected to produce a steeper than normal beach. Haterial finer than that occupying the natural beach will, when exposed on the surface, move seaward to a depth compatible with its si ze. Almost any ource of borrow near the shore will produce some material of proper beach size. Since the source of artificial nourishment will control the cost to a major degreo, oraluation of material charactoristics is an important factor in economic design. At present such evaluation must bo made largely on a basis of experience at other localities.

The beach crest height will bo ostablished ultimately by natural forces, that is, the cyclic changes in water level and the wave pattern. The foreshore and nearshore slopes will affect wave behavior and thus influence the natural beach crest hoight. If the beach fill is placed to an eleration lower than the natural crest height a ridge will subsequently develop along the crest. Concurrent high water stage and high waves will overtop the crest and cause ponding and temporary llooding of the backshore. Such flooding, if undersirable, may be aroided by fixing the berm height slightly abore the natural beach crest height. If there is an existing beach at the site, the natural crest height can be determined therefrom. Otherwise determination must bo made on a basis of comparison with other sites poseessing similar exposure characteristics and beach material. There is at present no acceptable theoretical basis for predicting beach crost height.

Criteria for specifying berm width dopends upon a number of factors. If the purpose of the fill is to restore an eroded bench damaged by a major storn, where inadequate natural nourishment is not a factor in the problem, the width may be detormined by the protective width which experience has demonstrated to be required. Where the beach fill is to serve as a stockpile, the berm width should be sufficient to provide for expected recession during the interrals between artificial replenishment. It is generally considered that the too of fill of atockpile beach should not extend to such depth that transport of any material forming the surface of the fill would be retarded. There are no firm specifications for this limiting depth at present but available data indicate, that depths of twenty feet below low water datum on seacoasts and twelve feet on the Great Lakes may be used safely. It is obvious that the initial slope of any beach fill must be steeper than that of the natural shore area upon which it is placed. Subsequent behavior of the slope depends principally upon the charactoristics of the fill material. Fills composed of material coarser than that found on the native beach will maintain a toeper than normal sope. Finer material tonds to form a flatter slope. In ordinary practice the initial fill slope is designed paralled to the local or comparable natural beach slope above low water datum, and slopes of 1:20 to 1:30 from low water datum to intersection with the existing bottom. It is unnecessary to artificially grade beach slopes below the berm crest, for they will be naturally shaped by wave action.

The length of a stockpile beach may vary greatly depending upon local conditions. Lengths from a fow hundred feet to a mile have been 


\section{ARTIFICIALLY NOURISHED AND CONSTRUCTED BEACHES}

employed successfully. Since the updrift end of a stockpile beach will be depleted first, long stockpiles are usually nost suitable where a bulkhead or seawall exists to protect the backshore as erosion progrosses along the stockpile.

The foregoing general discussion of the derivation and use of the basic criteria pertaining to the artificial placenent of sand to maintain, rehabilitate or construct a beach clearly indicatos the laok of the present knowledge and consequently presents a chellenge to inrostigators to direct their work toward this phase of shore protection work. The principal factors which appear to warrant detailed study in order to establish more rigorous design criteria are the relations between the characteristics of beach and nearshore materials and their modes of transport; the relations between beach materials, exposure, and the resulting geometry of naturally formed besches; and more accurate mothods of detormining the deficiency in material supply on an eroding beach. In the present state of knowledge laboratory experimentation may be expected to contribute only to a limited degree to the solution of these problems. It is believed that emphasis must be placed on field investigation for this purpose, particularly in the form of follow-up studies of artiflcial beach fills.

\section{TYPES OF ARTIFICIALLY NOURISHED AND CONS TRUCTED BRACHES}

\section{OFFSHORE DEPOSIT METHOD}

This mothod of beach nourishment is constantly coning to the mind of the shore protection engineer sinoe a large supply of beach material could be made available at comparatively low cost in connoction with hopper dredge operations in coastal harbors.

A test of this type of nourishment was made in 1948 and 1949 by the Beach Erosion Board and the New York District, Corps of Engineers, Department of the Army at Long Branch, N. J. (reference 1) The city of Long Branch is looated near the northern tip of New Jersey adjaoent to the entrance to New York harbor. (Figure 1) It lies on a slight rise in the surrounding terrain, whioh slopes seamard to an elevation of 20 foet and terminates at the shore at the crest of a timber bulkhead rotaining Ocean Avenue. The beaoh fronting the bulkhoad is rolatively steep and narrow and is intersectod by numorous heary mubble mound groins.

The history of the Long Branch area has been one of progressive orosion caused by the stabilization of updrift areas which formerly oroded and supplied abundant littoral terial to down drift areas.

The purpose of this test was to determine the feasibility of restoring an adequate littoral drift to nourish the shore by employing natural forces to move material, dumped in relatively deep water, shoreward toward the beach. 


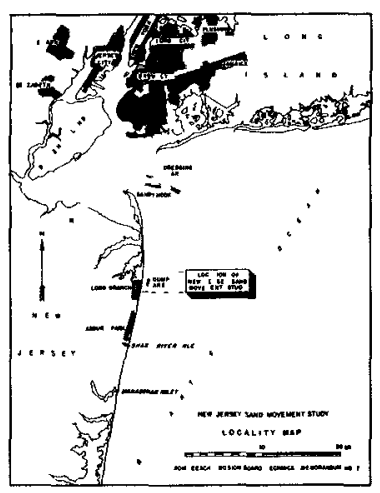

Fig. 1. Looality map, Long Branoh, N.J.

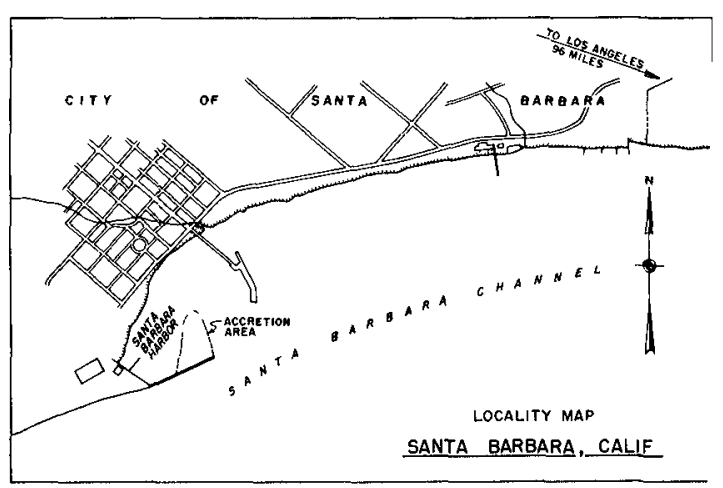

Fig. 3. Looality map, Santa Barbara, Cal

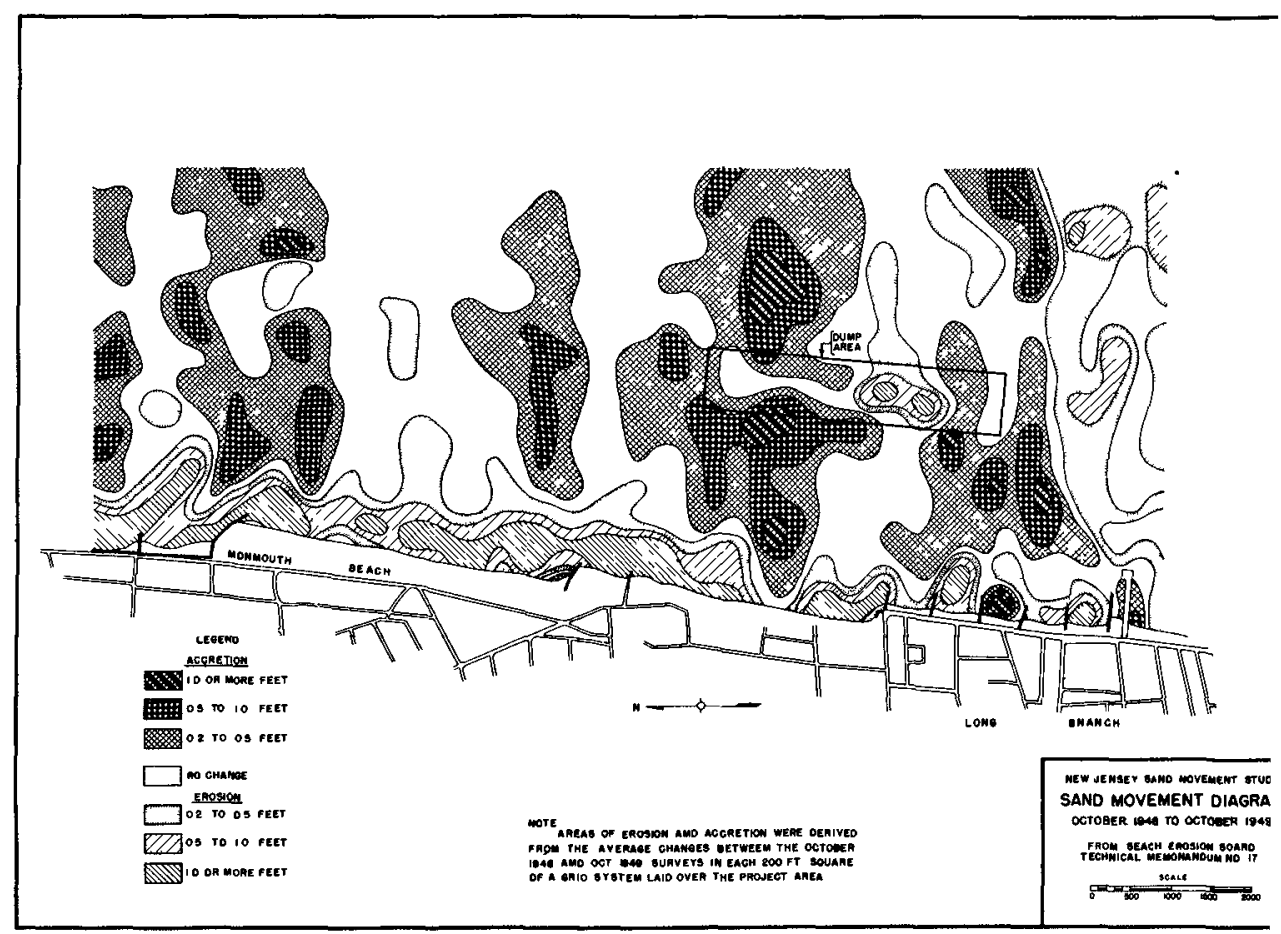

Fig. 2. Sand movement diagram, Long Branch, N.J. 


\section{ARTIFICIALLY NOURISHED AND CONSTRUCTED BEACHES}

The material dredged from New York Harbor entrance ohannels was pleoed in a ridge about 7 fert high, 3,700 fert long and 750 fert wide, lying ebout $\frac{1}{3}$ mile fram shore in a depth of 38 feet below mean low water, with its southerly limit on an east west line about 1500 feet north of the Long Branoh Pier. Dumping at the site amounted to a total of 602,000 cu. yds. of sand. (Figure 1)

During the entire period of study, oceanographic foroes effeoting sand movement were recorded and the sand movement was traced by periodio hydrographio surveys oovering the area from the Long Branoh Fishing Pier northward to Monmouth Beaoh Coast Cuard Station and from the bulkhead line seaward 6,000 feet to about the 42 foot depth oontour (mean lor water). An effort to trace sand movement through dissimilar minerals in the beach and dumped sand failed. At this point one may question the suitability of the Long Branch site for a study of this nature. Dceanographio and hydrographio data oollected at the site proved its suitability since natural forces were found whioh were oapable of moving material over the ooean floor in 35 to 40 feet of water and along the beaoh.

The result of the sand morement during the period Dotober 1948 after all dumping had been completed to Notober 1949 are depicted by net bottom changes and are shom on Figure 2. The bottom ohanges show aooretion to be general over the offshore area inoluding the mound. An area of looalized erosion developed near the center of the mound and erosion occurred over the shoal at the southern limit of the study area. Nearshore erosion has been extensive over the year. The general accretion over the mound ooupled with the extensive erosion along the shore indicates that the deposited material, during the period of observation, has not benefited the beaoh. While observations over a longer period may indicate some benefit, it may be conoluded from present evidence that this method will not provide nourishment at a suitable rate to justify its general use.

The oonclusions reached in this study confirm the findings of two similar studies, one made at Santa Barbara, California where 202,000 ou. yds. of sand were deposited in 20 feet of water (mean lower low water) in September 1935, and the other at Atlantio City, New Jersey where $3,554,000 \mathrm{cu}$. yds. of sand were deposited off the beaoh in 18 to 20 feet of water (mean low water) during the period April 1935 - September 1943.

Although the results of this test to artifioially nourish the beach at Long Branoh, New Jersey, were negative, it is felt that they have a plaoe in this paper to guide future work al ong these lines.

\section{STOCKPILE METHOD}

Probably the first shore proteotion project designed speoifically for employment of this mothod was that doveloped at Sante Barbara, California (Figure 3). This projeot has been in sucoess rul operation 


\section{COASTAL ENGINEERING}

since 1938. Detalls of the plan are contained in references 2 and 3 and only a summary will be presented herein.

The problem at Santa Barbara was created by construction of a breakwater, completed in 1929, which effectively blocked the movement of littoral drift. Material accumalated on the updrift side of the breakwater at a rate in the order of 300,000 cubic yards a year. By 1934 the impounding capacity above the breakrater was reached, and the zone of entrapment shifted to the protected waters within the harbor.

Meanwhile beaches domdrift from the harbor, being deprived of normal nourishment, were progressively eroding. By 1938 the erosion area had denuded the down drift beaches for a distance of ten miles, to a location where a large natural sand deposit served to maintain shores beyond. Offshore deposit of sand removed from the harbor by hopper dredge in 1935, described earlier, failed to aid the shore. Damages mounted and hastily built shore protection structures provided little relief.

In 1938 a cooperative project was developed on recommendation of the Beach Frosion Board providing for establishing a tockpile beach fill along 4000 feet of shore down drift from the harbor, to be initially filled and periodically maintained with material dredged from the harbor. The first fill was completed in July 1938 and replenishnent has been accomplished at two or three year intervals since that date. The seventh repetitive nourishment operation is in progress at this time (October 1952).

By 1945, seven years after initiation of the project, stable conditions had been restored over the entire ten miles of previously eroding beach. No additional shore protection measures have been required since that date. The average rate of artificial nourishment in round figures, has been 300,000 cubic yards a year. The average cost is 21 cents a cubic yard. Harbor maintenance as well as shore protection is acconplished, and under the terms of the project the United States pays the cost of the former by the cheapest method (hopper dredging) at an established price of 13 cents a cubic yard. The work is accomplished with conventional pipe line dredging plant and equipment. Local intereste contribute the added cost of depositing the material on the stockpile beach, an average of 8 cents a cubic yard or $\$ 24,000$ a year. Considering the length of frontage receiving protection in this project, the average annual cost is about 50 conts a linear foot. This is a ninor fraction of the cost experienced where defensive works are employed for shore protection.

A more recent example of stockpiling and on a beach to be distributed along the down drift shore by the, natural forces is the project undertaken several years ago at Palm Beach, Florida.

Palm Beach is located on the coastal lorlands of the east oost of Florida about 300 miles south of Jacksonville and 70 miles north of 

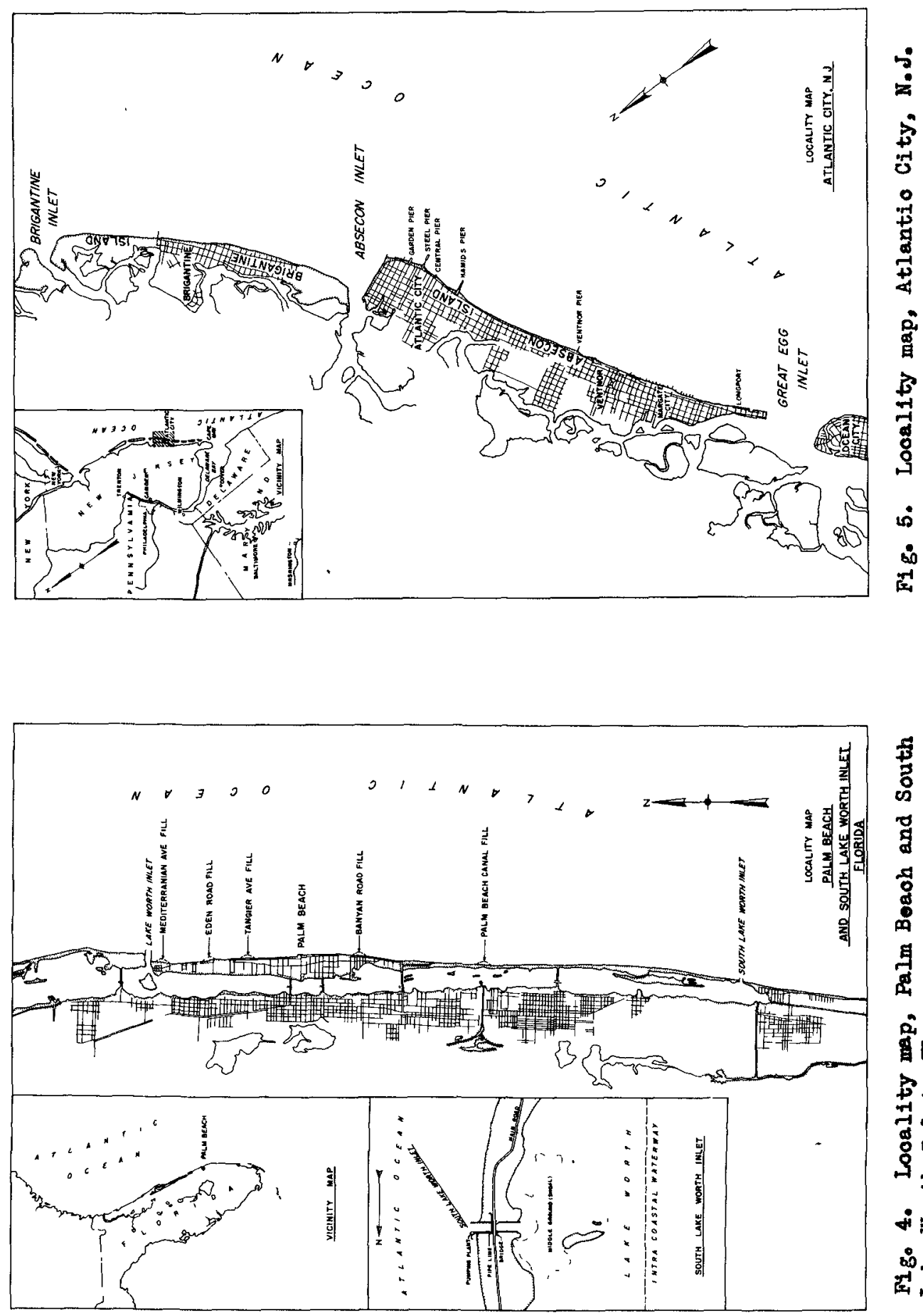

番 


\section{COASTAL ENGINEERING}

Miami Beach. (Figure 4) The barrier beach on which the town has been built separates Lake Worth from the Atlantic Ocean and is breached by two inlets, Lake Worth Inlet and South Lake Worth Inlet, about 15.5 miles apart. The barrier is composed principally of sand, part of which is artificial fill over former marsh areas. There are occasional outcroppings of coquina on the barrier and in the offshore area.

Lake Worth Inlet was dredged through the barrier and two protective jetties were constructed between 1918 and 1925. The construction of the jetties have caused changes in the adjacent shore lines similar to those at a number of other inlets along the east coast of Florida where jetties have been constructed; namely, accretion north of the north jetty and erosion south of the south jetty. An accurate estimate of the rate at which the littoral drift has been impounded by the north jetty cannot be made from available historical records but a number of rough estimates have been made utilizing available information. These estimates although rough, indicate the limits of the range between which the true value probably lies. They indicate that during the 14 years period immediately following completion of the inlet and jetties, material was impounded at a rate averaging 150,000 to 225,000 cubic yards per year and that during the next seven years the rate approximuted 130,000 cubic yards per year.

The removal of this quantity of material from the littoral stream which formerly nourished the $\mathrm{Palm}$ Beach shores has resulted in continuous erosion. The rate of erosion has been retarded by the construction of a fairly uniformly spaced field of groins but in general the groins have not maintained as wide a beach as desired, primarily because of the lack of sufficient littoral drift.

Studies made by the Beach Erosion Board in cooperation with the Port of Palm Beach District to develop a plan or plans for the rehabilitation and future protection of $\mathrm{Palm}$ Beach resulted in the conclusion that because of the absence of an assured natural supply of beach material an artificial supply must be furnished. (reference 4) It was al so conoluded that the best method of nourishing this shore would be to pump sand from Lake Worth and place it in stockpiles along the beach. The decision to use this method of nourishment was due in part to a satisfactory test of stockpile nourishment made on the beach immediately south of Lake Worth Inlet in 1944.

The recommendations made by the Board were accepted by the cooperating agency and four stockpiles of sand were placed on the beach between May and November 1948. An additional stockpile of 100,000 cu. yds. of sand was placed on the beach opposite the West $\mathrm{Palm}$ Beach Canal by Palm Beach County in 1949. The quantity of material placed in each of the stockpiles together with previous and subsequent placements near the northern end of the beach and the locations of the piles are shown on Figure IV and in the following table. 
Location

Mediterranean Ave.

Eden Road

Tangier Ave.

Banyan Road

Hest Palm Beach Canal
Date of Placement

$\begin{array}{ll}\text { Aug. } & 1944 \\ \text { May-Nor. } & 1948 \\ \text { July } & 1949 \\ \text { Kay-Nor. } & 1948 \\ \text { May-Nov. } & 1948 \\ \text { May-Nor. } & 1948 \\ & 1949\end{array}$

No.Cu.Yds.

300,000

215,690

380,000

630,600

454,640

$1,035,000$

100,000
Cost per Cu.Yd.

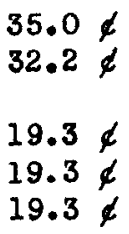

The results obtained through the use of stockpiles to nourish the beach in the Palm Beach area can best be described by the following statements made by Mr. Horman C. Schmid, Engineer, Town of Palm Beach. "It is my opinion that artificial sand supply is the best mothod of beach protection that we have found in Palm Beach. The only trouble is that we have only cupplied the beach with two and one half million yards and it is estimated that the project would require six million in order to bring the beach line to the 1928 location." Mr. Schmid further states that past experience shows that, "The northernmost stockpile should be replenished yearly, the others to the south every two or three years depending upon storm conditions". He concludes " - - that the sand has moved as expected, also that the experiment even to the layman's eye has proven quito successful".

\section{CON TINUOUS NOURTSHMWN TETHOD}

One of the best examples of continuous nourishment to a beach down drift from an inlet is the sand bypassing plant at South Lake Worth Inlet, Morida. The factors pertinent to the installation of and the results obtained with this bypassing plant were thoroughly covered by Mr. Joseph M. Caldwell in the first Coastal Engineering Conference but since it is the intent of the writer to make this paper as complete as possible in the field of artificial nourishment the highlights of this installation $\mathbf{w l l}$ be briefly reviewed.

South Lake Worth Inlet is located on the east coast of Florida near the southern limit of Lake North which separates the mainland from the sand barrier on which the tom of Palm Beach is located. (Figure 4 )

This inlet was drodged through the barrier in 1927 by the South Lake Worth Inlet District to create a circulation of water in the southern end of the lake to relieve the otagnant condition of the waters. The inlet was fixed by two short jetties about 250 feet 1 ong. Due to tho abundant littoral drift from north to south in this area the littoral reserroir formod by the north fetty was quickly filled and sand was carried around its outer end into the inlet where it aroppod out of suspension forming a middle ground shoal.

Concurrently with the filling of the impounding area behind the north jetty and the formation of the shoal, the beach south of the inlet eroded. Property owners faced with the loss of valuable land and homes constructed numerous protective structures but due to the inpounding of the natural supply by the inlet, these structures did not help in holding or building a protective beach. The fallure of the 


\section{COASTAL ENGINEERING}

struotures to protect the area clearly indicated the necessity of rebuilding the beach as a protective barrier through the restoration of the littoral drift in the area. This was done by establishing a pumping plant on the north jotty to bypass the sand across the inlet to the eroding shore. The distribution dow beach of this material was left to the action of natural forces. This method had the added advantage of reducing the sand available to be carried into the inlet to be deposited on the middle ground shoal.

The pumping plant was not designed to bypass the entire quantity of littoral drift but rather to supply the quantity of material required to restore the beaches to the south. During the first five years of operation prior to World War II about 250,000 cu. yds. of sand were supplied to the beach. The benefit derived from this operation was felt almost inmediately and at the end of the five year period the beach south of the inlet was entirely restored. During this period shoaling decreased over the middle ground.

The cost of moving the sand including operation, maintenance, and depreoiation was about 9 cents per cubic yard. Based on current prices the figure would still be well under the 19.3 cents to 35.0 cents per cubic yard cost of the stockpile nourishment placed on Palm Beach from Lake Worth.

It is recognized that although the sand has been moved economically with a fixed plant at South Lake Worth Inlet periodic nourishment using a floating plant may be more economical at other littoral barriers.

\section{DIRECT PLACEMONT TETHOD}

It differs from the stockpile method in that the fill is completed at one time orer the entire shore to be protected. In effect it may subsequently take the form of a tockpile project since it will serve as a supply source for the down drift shore, and future maintenance may be accomplished by artificial nourishment of those areas which first demonstrate supply deficiency by erosion.

This type of beach rehabilation was used at Atlontic City, New Jersey in 1948 to quickly restore the ocean beach which was eroded to a point where it furnished little protection during fall and winter storms to the boardwalk and valuable real estate investments. (reference 5)

Atlantic City is located on the oosst of New Jersey about 45 miles northeast of Cape May, the southern tip of the State at the entrance to Delaware Bay. (Figure 5) It comprises nearly one-half of the length of the barrier beach bnown as Absec on Island. Absecon Inlet is the northeastern boundary of the city and Island.

Because of its location near extensively developed and densely populated urban areas, being about 60 miles from Philadelphia and 125 


\section{ARTIFICIALLY NOURISHED AND CONSTRUCTED BEACHES}

miles from New York City, it has rapidly become the most popular resort of its kind in the country.

The ocean beach is generally wide and flat; supplied with material transported southwrard alang Brigantine Island. The volume of sand moving along this shore cannot be accurately determined but dredging figures indicate that it may be about 400,000 cubic yards per year. The part of this quantity mored onto the Atlantic City beach by natural forces is not known. Studies show that the beach remained relatively stable prior to 1940 and then started to erode progressively for a distance of about 6,000 feet southwest of the inlet. In view of the natural condition extant in the area and the imnediate need for a protective beach southwest of the inlet, the State of New Jorsey and the City replenished the beaches with sand moved by hydraulic dredge and pipe line from the point of Brigantine Island across the inlet. Approximately 700,000 cubic yards of sand were deposited on the beach from the Oriental Avenue Jetty to a point about midway between Central and Hamid's Piers during the summer of 1948. This material was placed on the beach over its 6,000 foot length at a cost of 77 cents per cubic yard.

Imediately prior to placing the fill a stone jetty was constructed on the south side of the inlet to divert the channel eastward away from the beach.

Subsequent to placing the artificial fill, an existing groin was repaired and five others were constructed to retard the loss of sand from the beach. Replenishment of the material placed on the beach has not been made but will be made when necessary.

The results obtained through the direct placement of sand to the beach at Atlantic City has been as successful as the studies had indicated. Observations made at rarious intervals following the period of beach slope adjustment show the beach to be relatively stable. It is too early to determine maintenance requirements and costs, but indications to date are that maintenance by periodic nourishment will be both feasible and economically preforable.

In sumary, it is believed that artificial nourishment is firmly established as a practicable and economic means of shore protection which must be considered and evaluated in comparison with al ternative measures in the study of any erosion problem. The long term benefit of this method of protection with respect to very substantial lengths of shore is important aspect to be considered. Extensive additional research is needed to establish proper design criteria and a more accurate basis for economic analysis of this method.

\section{ARTIPICIRULY NOURISHED BEACHES IN THE UNITED STATES}

The purpose of this section of the paper is to assemble in one document all information available in the records of the Beach Erosion Board including published references 6 to 12 pertaining to those beach 


\section{COASTAL ENGINEERING}

areas of the United States which have been artificially nourished or constructed. The data is presented in throe parts in tabular form; the first outlines basic information on the beach required for the design of its nourishment; the second outlines information pertaining to the material available for the nourishnent; and the third outlines information pertaining to the stabilized beach. Although an effort has been made to include all of the known artificially nourished beaches in the United States in the table there are undoubtedly many that have been overlooked. In several of the cases listed the purpose of the beach fill was not shore nourishment but simply selection of a convenient disposal area for dredged material. Those have been included for possible future use of the data presented(see Appendix).

\section{ACKN OMLFDGEMENT}

The author is indebted to Mr. R. O. Eaton, Chief Technical Adviser to the President of the Beach Erosion Board for many helpful suggestions made during the preparation of this paper and to Mr. G. P. Magill of the Boards' staff who assisted in searching the literature and records.

\section{RE FERENCES}

(1) Hall, Jay V., Jr. and Herron, W. J. (1950). Test of nourishment of the shore by offshore deposition of sand, Long Branch, N. J.: Tech. Memorandum No. 17, Beach Erosion Board, Corps of Engineers, Department of the Army, Washington, D. C.

(2) Corps of Engineers, Department of the Army (1950). Beach Erosion at Santa Barbara, California: House of Representatives, Document No. 552, 75th Congress, 3rd Session.

(3) Corps of Engineers, Department of the Arny (1948). Santa Barbara, California, Beach Brosion Control Study: House of Representatives, Document No. 761, 80th Congress, 2nd Session.

(4) Corps of Engineors, Department of the Army (1948). Palm Beach, Fla.: Beach Erosion Study: House of Representatives, Document No. 772, 80th Congress, 2nd Session.

(5) Corps of Engineers, Department of the Arny (1950). Atlantic City, N. J., Beach Erosion Control Study: House of Representatives, Document No. 538, 81st Congress, 2nd Session.

(6) Corps of Bngineers, Department of the Army (1948). Harrison County, Mississippi, Beach Erosion Control Study: House of Representatives, Document No. 682, 80th Congress, 2nd Session.

(7) Corps of Engineers, Department of the Army (1950). South Shore, State of Rhode Island, Beach Brosion Control Study: House of Representatives, Document No. 490, 81st Congress, 2nd Session. 


\title{
ARTIFICIALLY NOURISHED AND CONSTRUCTED BEACHES
}

(8) Corps of Engineers, Department of the Army (1942). Beach Erosion Study, Coronado, Califo: House of Representatives, Document No. 636, 77th Congress, 2nd Session.

(9) Corps of Engineers, Department of the Army (1936). Beach Erosion at Jacob Rils Park, Long Island, H. Y.s House of Representatires, Document Ho. 397, 74th Congress, 2nd Session.

(10) Corps of Bngineers, Department of the Army (1937). Study of an Artificial Bathing Beach at Orchard Beach, Pelham Bay, H. Y.s House of Representatives, Document Ho. 450, 75th Congress, 2nd Sersion.

(11) Corps of Engineers, Department of the Army (1934). Wrighteville Beach, N. C.: House of Representatives, Document No. 218, 73rd Congress, and Session.

(12) Corps of Engineers, Department of the Army (1940). Beach Erosion Study, Orange County, Calif.: House of Representatives, Document No. 637, 76th Congress, 3rd Session.

\author{
APPBNDIX \\ TABULATED DATA ON ARTIFICIALLY NOURISHED \\ AND CONSTRUCTED BEACHES
}

Tablø 1

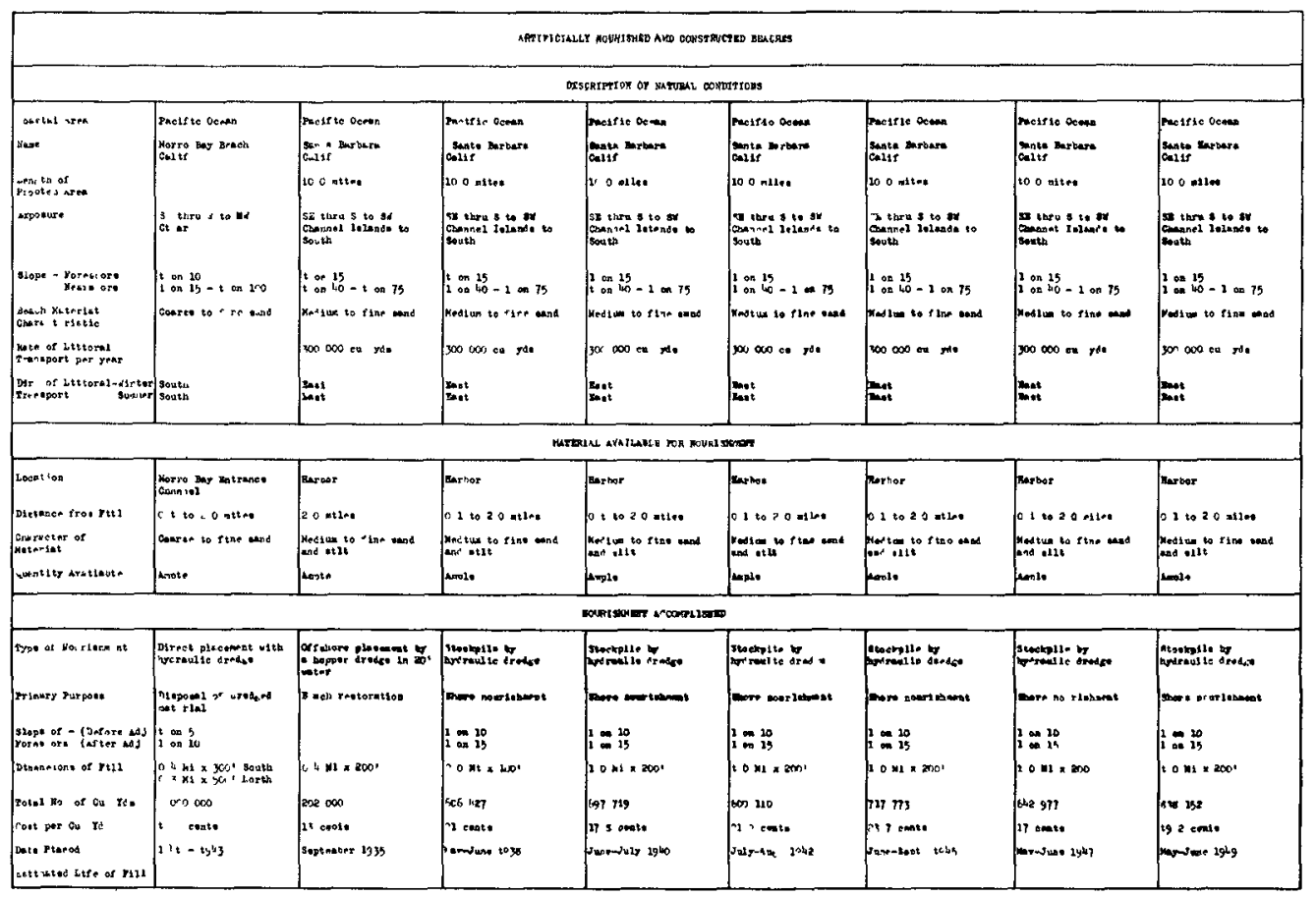


COASTAL ENGINEERING

Pablo 2

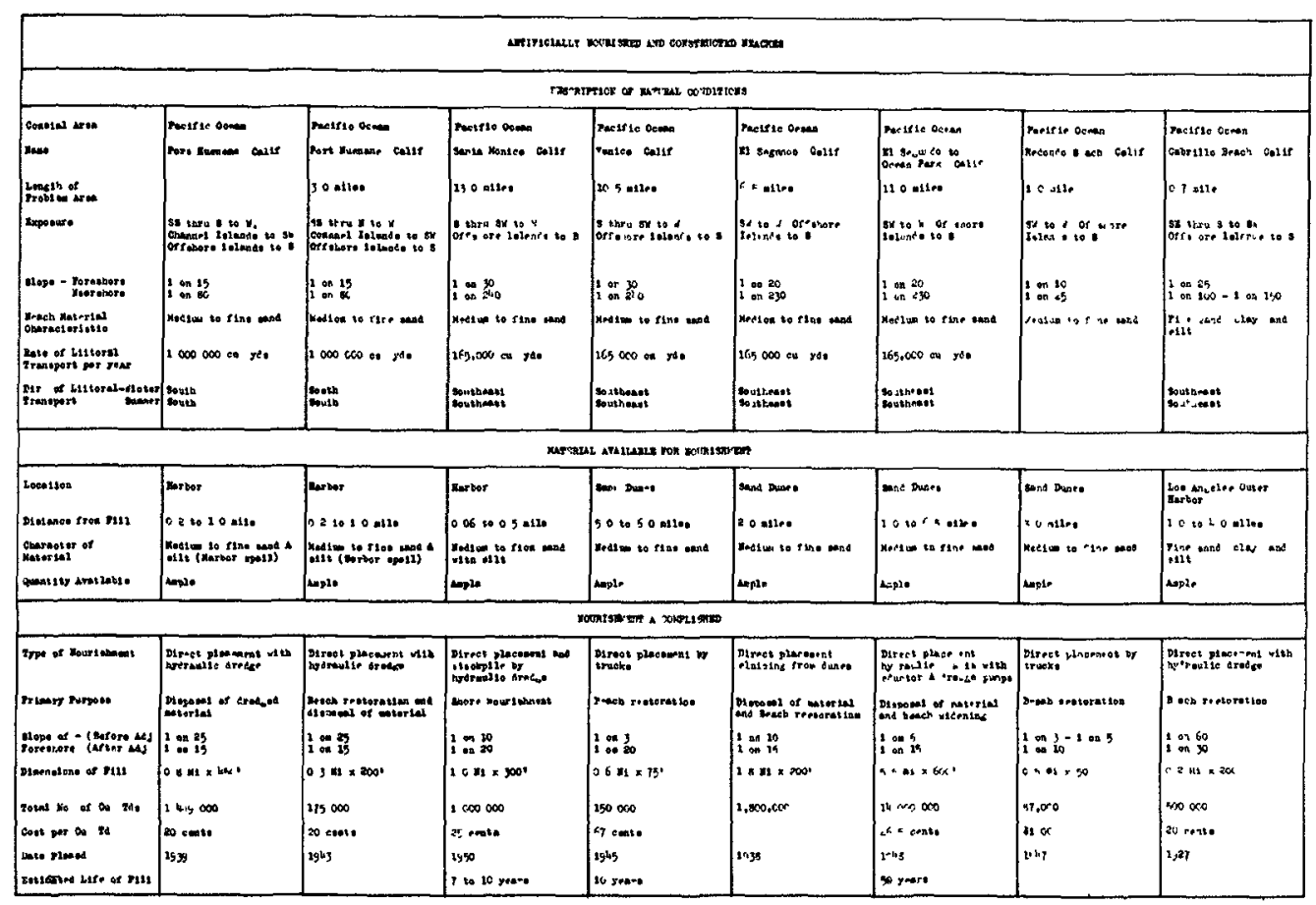

Table 3

\begin{tabular}{|c|c|c|c|c|c|c|c|c|}
\hline \multicolumn{9}{|c|}{ 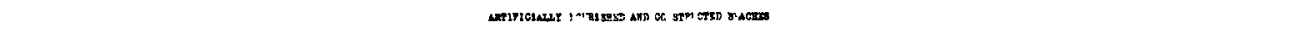 } \\
\hline \multicolumn{9}{|c|}{ 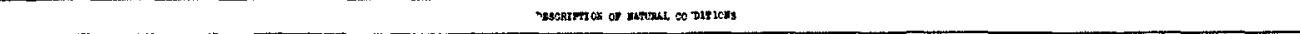 } \\
\hline 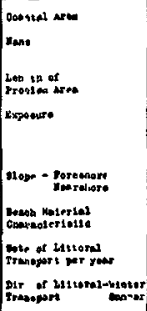 & 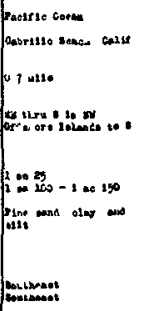 & 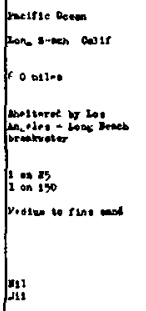 & 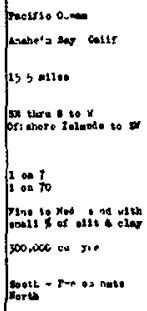 & 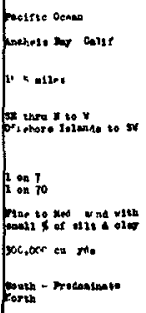 & 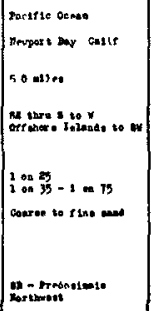 & 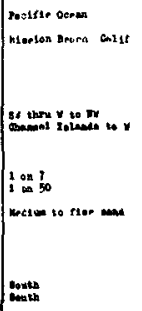 & 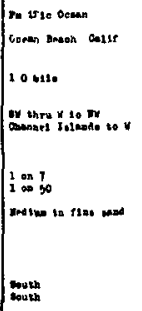 & 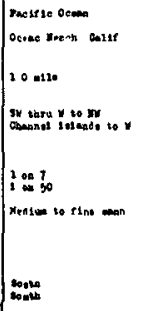 \\
\hline \multicolumn{9}{|c|}{ 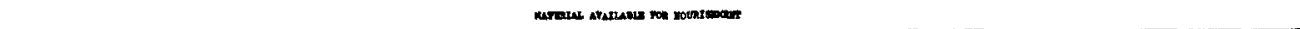 } \\
\hline 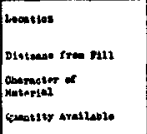 & 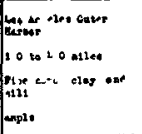 & 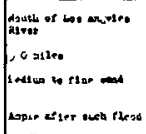 & 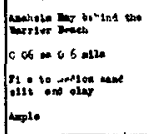 & 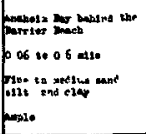 & 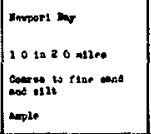 & 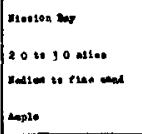 & 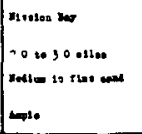 & 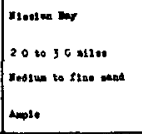 \\
\hline \multicolumn{9}{|c|}{ 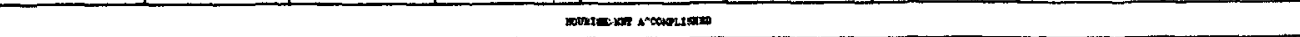 } \\
\hline 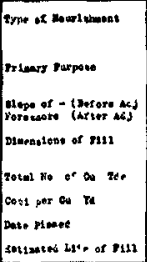 & 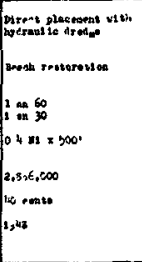 & 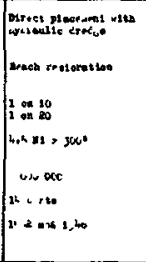 & 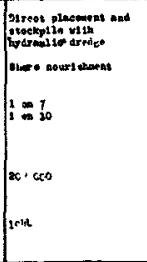 & 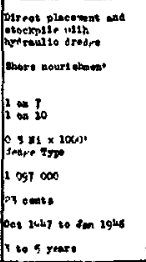 & 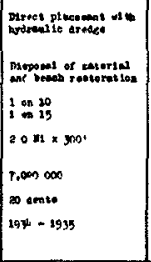 & 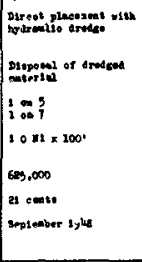 & 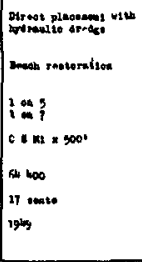 & 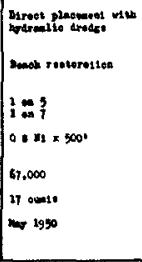 \\
\hline
\end{tabular}




\section{ARTIFICIALLY NOURISHED AND CONSTRUCTED BEACHES}

Table 4

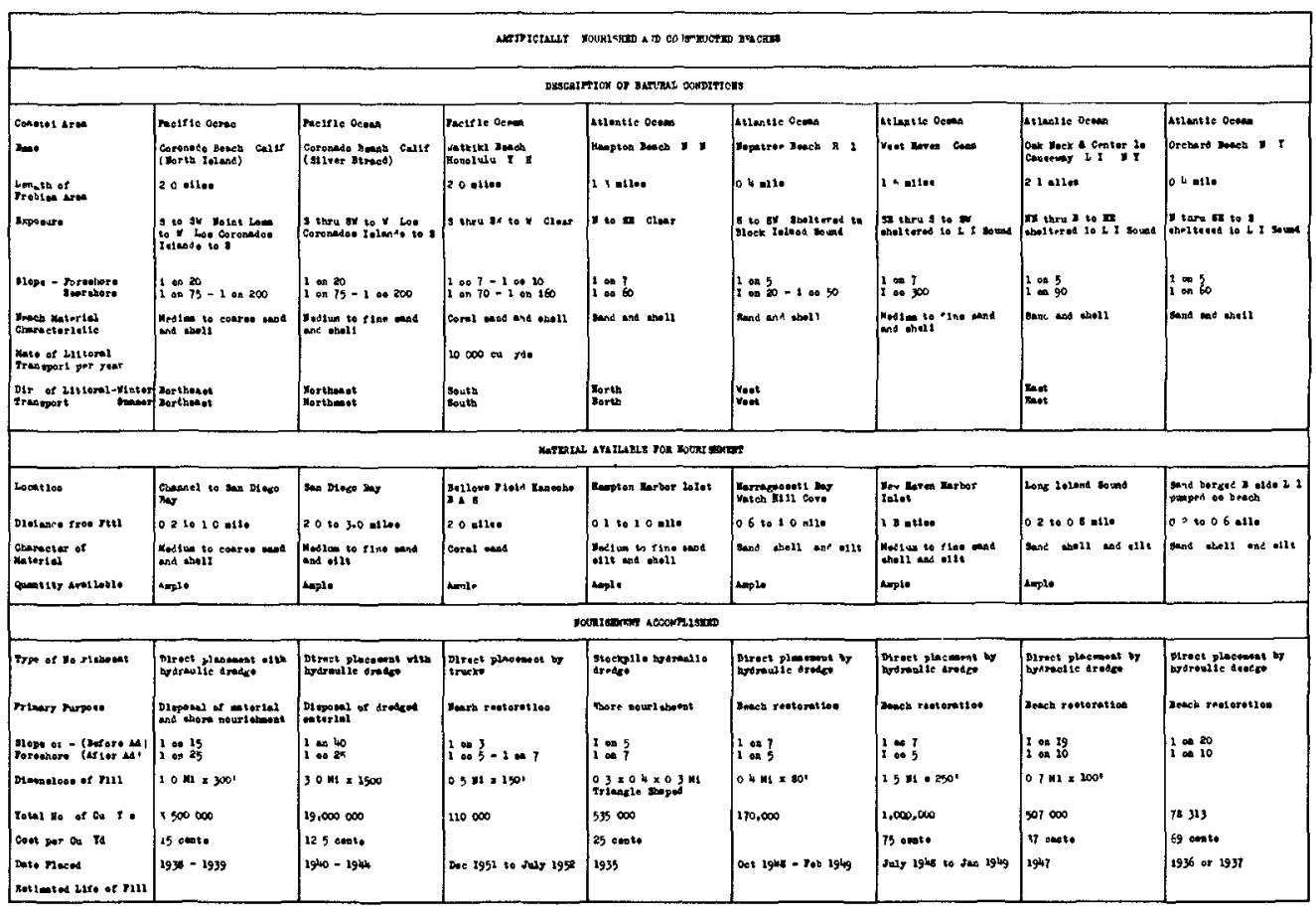

\section{Tablo 5}

\begin{tabular}{|c|c|c|c|c|c|c|c|c|}
\hline \multicolumn{9}{|c|}{ 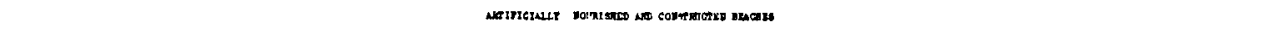 } \\
\hline \multicolumn{9}{|c|}{ 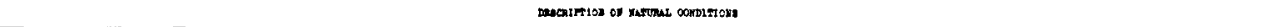 } \\
\hline 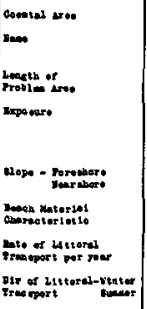 & 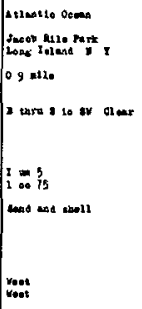 & 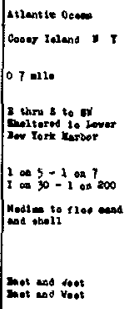 & 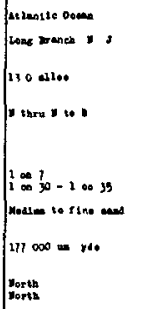 & 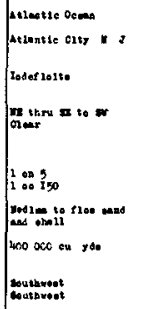 & 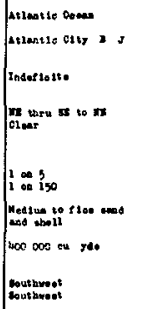 & 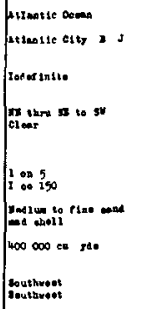 & 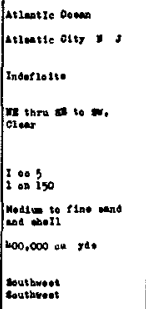 & 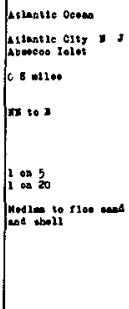 \\
\hline \multicolumn{9}{|c|}{ 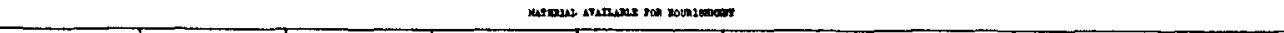 } \\
\hline 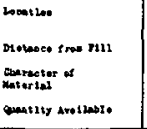 & 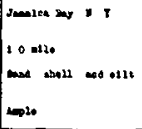 & 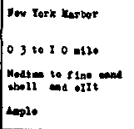 & 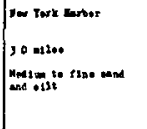 & 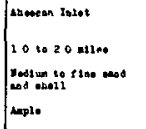 & 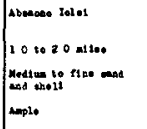 & 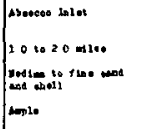 & 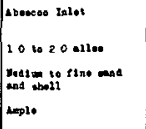 & 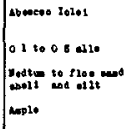 \\
\hline \multicolumn{9}{|c|}{ 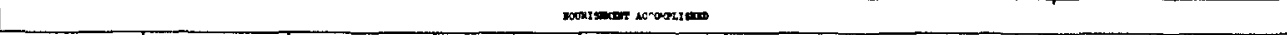 } \\
\hline 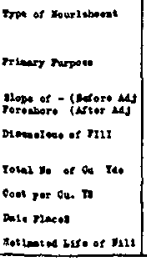 & 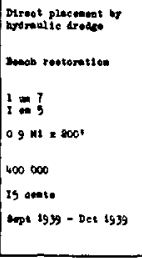 & 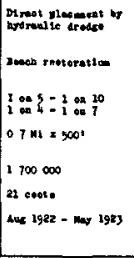 & 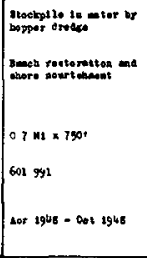 & 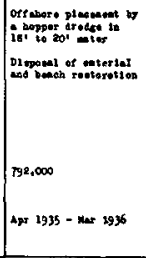 & 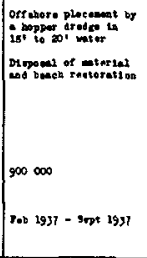 & wue $1938-\cos 19 \mu$ & $\begin{array}{l}2,362000 \\
24061942-\operatorname{soph} 1943\end{array}$ & 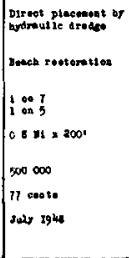 \\
\hline
\end{tabular}




\section{COASTAL ENGINEERING}

Table 6

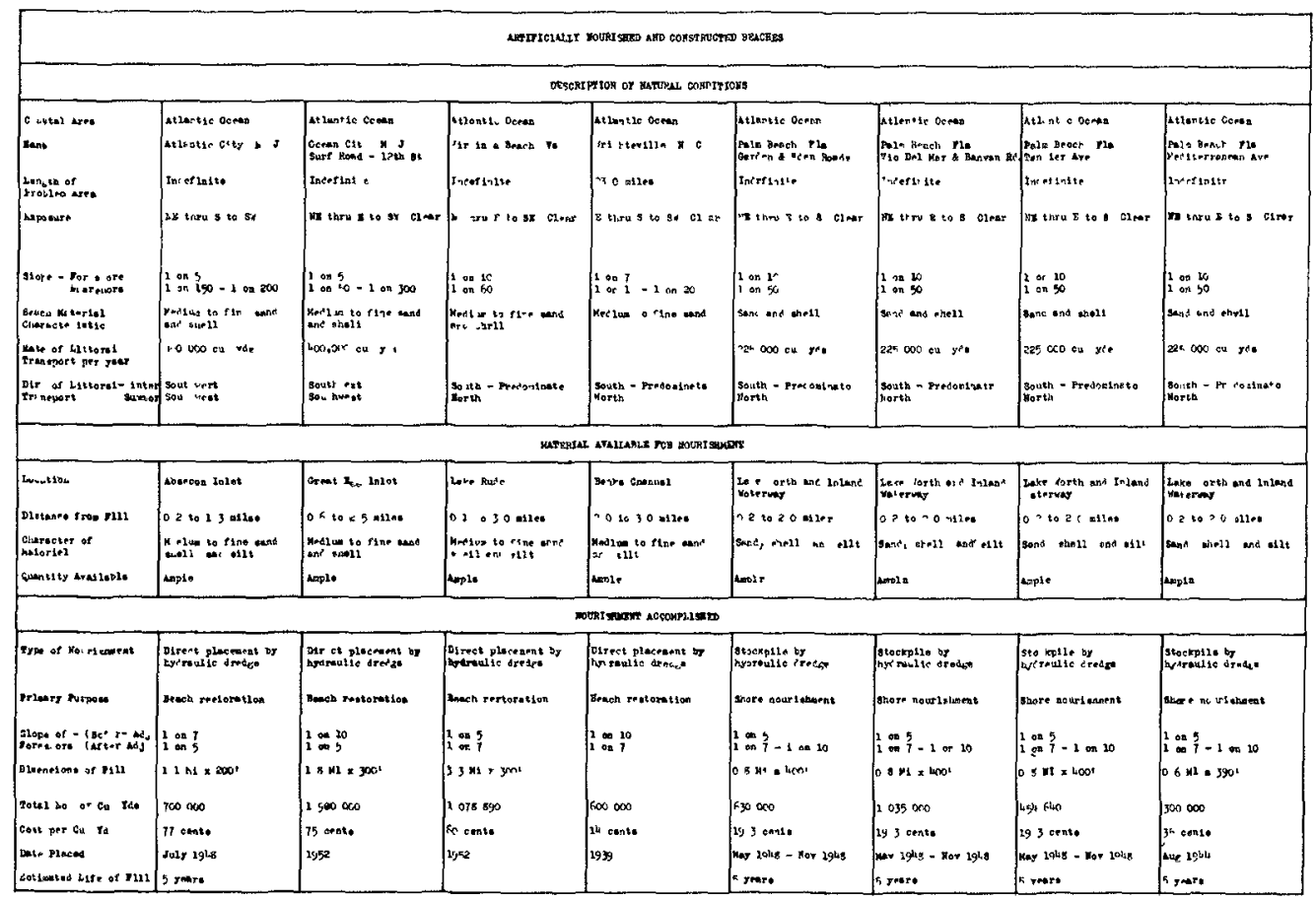

Tablo 7

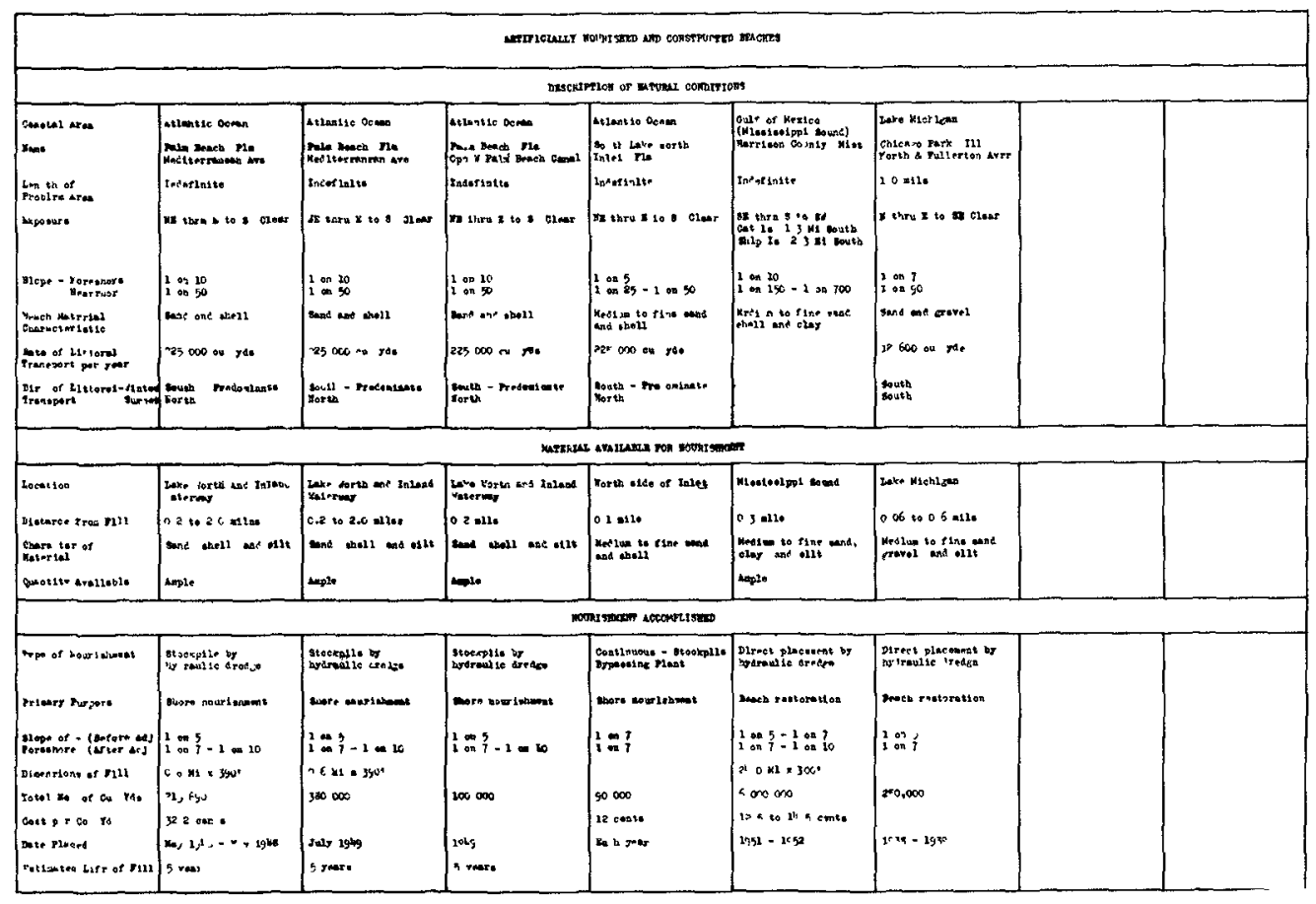

